\title{
Digital Libraries and Copyright in Poland
}

\author{
Teresa Święćkowska \\ Institute of Information and Book Studies, University o Warsaw
}

\begin{abstract}
Purpose/thesis: The article presents results of preliminary research on copyright issues in Polish digital libraries. The aim of the research was to identify main copyright questions and issues faced by digital librarians in Poland.

Approach/methods: The research is based on interviews with Polish digital librarians and the analysis of documents concerning copyright and digital libraries in Poland.

Results and conclusions: The restrictive approach to copyright limits the field of activity of digital libraries.

Originality/Value: The article shows that Polish librarians are challenged by locally specific problems resulting from Polish approach to exceptions from and limitations to copyright and unclear rights, particularly as regards the symbolic production of the People's Republic of Poland.
\end{abstract}

Keywords

Digital libraries. Copyright. Orphaned works. Poland.

Received: 6 November 2015. Revised: 24 December 2015. Accepted: 27 December 2015.

\section{Introduction: Digital Technologies in the Stranglehold of Copyright}

New technologies have given libraries a huge potential of expanding their traditional functions and meeting important new challenges. Digital collections take up less space, they can be full-text searched and of course they can be made available over the internet. However, this potential cannot be fully made use of. Copyright is one of the most important factors blocking the use of digital technologies by libraries. The changes in international copyright law which have been introduced at the turn of the millennium in order to adapt legislation to technological change, have explicitly confirmed the exclusive right of the author to make digital copies of her/his works ${ }^{1}$. This quickly made visible some absurdities in practice. Because of the way today's computerized infrastructure of the circulation of information has been engineered, the technical process itself demands the continuous creation of digital copies. When we open a web page on our computer screen, a temporary copy is created in memory. Strict literal compliance with copyright principles would paralyze network communication - not to mention freedom of speech. This is an extreme

\footnotetext{
${ }^{1}$ Agreement on Trade-Related Aspects of Intellectual Property Rights (TRIPS, 1994); Digital Millennium Copyright Act (DMCA, 1998); Directive 2001/29/EC of the European Parliament and of the Council of 22 May 2001 on the harmonization of certain aspects of copyright and related rights in the information society (Directive EC, 2001).
} 
example but it serves well to illustrate the possible consequences of a maximalist approach to copyright protection ${ }^{2}$.

The introduction of total protection from digital copying has severe consequences for digital libraries whose very existence and activity is based on the creation of digital copies. Protection from digital copying means that libraries will have to get the copyright owner's permission before any digital use of protected works. While the problem of temporary copies in technical information transfer processes has been solved by introducing a clearly defined exception from copyright ${ }^{3}$, the question of exceptions for libraries has not been solved unambiguously and is still a matter of negotiations and conflicting interpretations. What makes the problem even more complicated is that while international treaties demand the recognition of the general principle of protection from copying, exceptions from copyright are left to be solved by national law. This leads to a situation full of contradictions. For example, in 2013 a court in the United States decided that Google's creation of copies in order to create full text indices and present search results is covered by the principle of fair use ${ }^{4}$. European countries however do not provide such an exception for private subjects. Leaving aside the question of Google's monopoly, in practice this means that US residents might have better access to information than people living in other countries, including European Union, if legislation or courts there decide to limit access to Google's offer. The European Union also acknowledges exceptions from copyright, but these are limited to a certain catalogue and by additional qualifications which considerably hamper the creation of a national library policy (Directive EC, 2001) ${ }^{5}$.

Exceptions for libraries introduced into the Polish copyright law leave a lot of room for interpretation which in turn leaves libraries in an uncertain situation. There still are no court rulings of key questions regarding practical solutions, while some regulations lack clear interpretation. Librarians who want to create digital libraries therefore have to cope with extreme legal uncertainty when it comes to applying general principles of law to everyday practice. This uncertainty is further exacerbated by frequent changes in law and the lack of unambiguous interpretations of new laws, as well as by strong lobbying by publishers' associations who have been propagandising a very narrow interpretation of legal exceptions from copyright ${ }^{6}$.

${ }^{2}$ In The State of Copyright Debora Halbert describes how changes of law have been moving towards maximum protection over the last decades (Halbert, 2014).

${ }^{3}$ Directive 2001/29/EC in the article 5, paragraph 1 says: "Temporary acts of reproduction referred to in the article 2, which are transient or incidental [and] an integral and essential part of a technological process and whose sole purpose is to enable: (a) a transmission in a network between third parties by an intermediary, or (b) a lawful use of a work or other subject-matter to be made, and which have no independent economic significance, shall be exempted from the reproduction right provided for in the article 2 ". See also the article 23, paragraph 1 of the Polish Copyright Law of February 4, 1994.

4. On 14 November 2013, US Circuit Judge Denny Chin ruled in favour of Google in the matter of The Authors' Guild, Inc. et al v Google Inc. (05 Civ. 8136 (DC) (SDNY No. 14, 2013)).

5 Directive 2001/29/EC in the article 5 "Exceptions and limitations" enumerates a list of exceptions and limitations which can be introduced in member countries.

${ }^{6}$ An example is the report Analiza wptywu zjawiska piractwa treści wideo na gospodarke w Polsce [An analysis of the influence of the phenomenon of video content piracy on the Polish economy], commissioned by the Association of Television Program Distributors "Sygnał" and prepared by PwC Polska Ltd. in 2014. The report's authors' interpretation of the law denies the possibility of legal exceptions from copyright (PwC, 2014). 
In this article, I will try to sketch a rough map of the problems in the area of copyright with which digital librarians are struggling. This map is based on interviews with librarians from several major digital libraries in Poland and an analysis of material from debates and workshops on copyright among librarians ${ }^{7}$. The interviews were conducted with librarians responsible for digital collections. Among seven libraries chosen for interviews there were three regional public libraries (voivodship libraries), two university libraries and two institutions designated as competence centers for digitization (the Polish National Library and the National Audio-Visual Institute). The interviews were only roughly structured. They contained many open questions aimed at finding out what kind of problems concerning copyright digital librarians were faced with and how they dealt with them. Although the interviews were conducted before the amendment of 11th September 2015 to the Polish Copyright Law, the draft law was already known and had been publicly discussed.

The respondents were also asked about copyright clearing i.e. if and in which cases librarians undertook searches for copyright owners and how did they do this. The main aim of the research was to identify important legal questions for the Polish digital libraries. It was not focused on a statistical representation of what kind of legal questions appear in digital libraries.

\section{Digitization and Access to Digital Collections vs. Copyright Law in Poland}

The Polish Copyright Law of February 4, 1994 in the article 28, paragraph 2 says that libraries, archives and schools may

make copies or commission the making of copies of widespread works which belong to their own collections in order to complete, preserve or protect these collections (Ustawa, 1994, consolidated text: Ustawa, 2015).

The requirement that only works from libraries' own collections may be copied was introduced in the amendment of September 11, 2015. Some lawyers advocate a broad interpretation of this exception to allow for large scale retro-digitization (Barta \& Markiewicz, 2010, 178). Libraries however are very cautious in selecting collections and focus mainly on scanning books from the public domain because only works from the public domain may be made available online after digitization without the permission of the copyright owner. Even though the article 23, paragraph 3 gives libraries, archives and schools permission to

make works available for scientific or educational purposes with the help of information system terminals on the premises of these institutions,

this law introduces an element of uncertainty because it introduces the condition of "scientific or educational purposes". The wording of this condition raises the question whether and how public libraries should monitor the goals with which users make use of their digital

7 The analysis is based on post-conference material from conferences, seminaries and workshops dedicated to the problem of copyright in libraries and articles from professional journals (Sokołowska, 2013); (Stanisławska-Kloc, 2005); (Szczepańska, 2008); (Szczepańska, 2013); (Szczepańska, Bednarek-Michalska Stanisławska-Kloc, 2010). 
collections. Should libraries define user groups, e.g. university students, or give access only to certain kinds of material which might be defined as scientific and educational? (Szczepańska, 2007, 58). Any material from a library, even material which is evidently entertaining, may simultaneously serve scientific goals, and every library user, regardless of professional status, may have scientific goals so every narrow definition will be exclusive and prevent public libraries from fulfilling their statutory tasks.

The latest amendment to the Polish Copyright Law also explicitly regulates how copyrighted digitized works may be made accessible through library intranets. The article 28 , paragraph 3 explains that

making copies must not lead to an increase of the number of copies of works and to a growth of collections being, respectively, borrowed and made accessible (Ustawa, 2015).

Does it mean that libraries can make digitized works accessible only in ways resembling traditional library services? For instance, if the library has in its collection one copy of a certain copyrighted book, after digitization the electronic copy can be made accessible through the electronic library network only to one reader at a time. If such an interpretation is correct, digitization of protected works makes little sense for user service oriented libraries.

Another important problem for digital libraries is that Polish law does not foresee any exceptions for making copyright protected works accessible over the Internet. At a time when using information from the Internet is becoming a standard, depriving libraries of this possibility means hurting them. The European legislative framework outlined by EU directives does not rule out the introduction of such an exception but it demands paying an appropriate compensation for using the work in the context of the exception. This leads to a strange situation because the change of copyright law passed in September 2015 introduces the obligation of paying a compensation for borrowing in public libraries. Since libraries are now obliged to introduce systems of paying authors it would seem logical to introduce exceptions for online borrowing. In the Polish law however the public lending right refers only to printed works. The fee system which is to be introduced concerns only printed documents or disks containing audiovisual works for which libraries so far had an unconditional license regulated by law. This means that the Polish law implements compulsory regulations limiting the activity of libraries while not making full use of the possibilities given by the directives regarding the introduction of exceptions. This approach to copyright creates an obstacle to the continuation of the tasks and functions of libraries because it denies them the possibility to use modern communications infrastructure, thereby limiting them to an anachronistic position which is lost from the start ${ }^{8}$.

The above mentioned legal framework also influences the policy of choosing material for digital collections. Libraries generally digitalize material in order to make it available to users online. In the current legal framework they will therefore focus on older collections and stay away from the digitization of newer material. This approach also seriously hampers the creation of thematic collections because it limits the timeframe to the public domain.

8 This is a problem pointed out in statements made by Polish librarians' organizations and associations during public consultations regarding changes in copyright law. Examples are statements and opinions voiced by the Conference of Library Directors of Polish Academic Schools, the Poznan Foundation of Scientific Libraries, the EBIB Association and the Association of Polish Librarians (RCL, 2014). 


\section{Problems with the Public Domain}

Although the law clearly defines the principles determining which works belong to the public domain it is not always easy to apply these principles to the concrete library material. Works by individual authors are protected for 70 years after the author's death, while collective works and anonymous works without a known author are protected for 70 years after their publication. When a library considers using a work it must therefore establish the author's date of death. Searches for less known authors are sometimes complicated and not always successful. According to some lawyers, if the author's date of death is not known one should go back 140 years to be sure that a work is in the public domain ${ }^{9}$. After all, works published after 1875 might still be protected by copyright if we don't know the author's date of death.

Settling rights is especially cumbersome in the case of small individual works published in journals and newspapers. Some Polish digital libraries have given up trying to settle the rights to small works which have appeared in the press, taking the position that entire newspaper issues are protected for 70 years after publication. If one were to follow a restrictive interpretation and settle the rights to each individual work, digital collections of Polish journals would look much more modest. By applying a protection period of 70 years after publication, Polish digital libraries give access to journals not only from the 19th, but also from the 20th century published until 1939.

There are fewer and fewer works from the safely defined public domain which have not been digitized yet. Libraries are beginning to feel a lack of material for the expansion of digital collections. Some libraries define the public domain less cautiously than the 140 years mentioned above and assume that giving access to 100 year old works whose author's date of death cannot be established does not carry a great risk. When a library publishes such material it may add a warning note asking anyone who has a claim to rights to contact the library in order to settle further action. An example is the text added by the Mazovian Digital Library:

The creators of the Mazovian Digital Library have applied special attention to settling copyright questions regarding the works contained in the library. The form of access given is based on the MDL's knowledge. Anyone claiming copyright protection of works contained in the MDL is kindly asked to contact the MDL's administrators in order to settle the situation and introduce changes (MBC, nd).

Such disclaimers do not free the library from responsibility for copyright violations but might be grounds for clemency in the event of a court case.

Another problem for libraries is clearly defining which works are generally not protected by copyright. This regards, among others, metadata and especially abstracts and widespread descriptions of objects, e.g. in museums. Collecting those data and making them accessible is indispensable for carrying out information activities. The situation may be further complicated by the above mentioned latest change in the copyright law of 11 September 2015. The new law removes the article 30, paragraph 1 which stated:

Information or documentation centers may put together and distribute their own documentary studies as well as single copies, not larger than one publisher's sheet, of fragments of published works (Ustawa, 1994).

${ }^{9}$ Such a standpoint was presented by T. Barański during the legal workshop for librarians organized by the National Library of Poland in Warsaw (18th June 2010). 
The previous rule regarded printed texts. Legislators said they wanted to remove it as outdated because documentation was not put together based on printed texts any more. The removal of the piece of legislation in question has led to protests of information centers who have demanded that the current exception be adapted to today's technological standards ${ }^{10}$.

\section{Orphaned Works}

Libraries which want to add works from outside the public domain to their digital collections must engage in a tedious process of settling rights and getting permission for using works. From the experience of libraries which have undertaken this process we know that this work is frustrating, not least because of orphaned works, i.e. works to which copyright owners cannot be found or cannot be contacted even if they can be found. The status of graphical works, photographies, or maps is particularly difficult to establish because these works are usually not signed with the author's name. They constitute an important part of library collections but remain "frozen" and inaccessible for the wider public because their legal status cannot be established.

Until September 2015 in Poland there were no legal solutions regarding the use of orphaned works, which means that they could not be legally used in protected areas. Many Polish libraries looked helplessly at the huge amount of frozen 20th century collections to which copyright had not been settled. The new law introduces an exception regarding the use of orphaned works by libraries, as a result of the implementation of the EU directive 2012/28/EU (Directive EU, 2012). According to the bill, orphaned works can only be made available after conducting a diligent search.

As mentioned before in the introduction, the interviews were carried out before the new law was introduced, but the bill was already known and being discussed among librarians. Most of the respondents were happy that the legislation about orphaned works was going to be introduced at all although they were also skeptical about the requirement of the diligent search. The requirement of the diligent search means that libraries will be faced with a new and tedious task which in practice will not do anything to speed up the digitization of works with an unclear copyright situation and access to them. None of the libraries employs specialists for copyright clearance. The librarians were also skeptical about possibilities of creating such a position in the future, considering library budgets. Most likely libraries will be faced with the additional bland task of settling rights without the support of new and specialized staff.

Apart from conducting the diligent search the new law imposes many other administrative tasks on libraries which want to use works with uncertain copyright status. In practice libraries would be responsible for the establishment of the status of orphaned works and also for possible compensation in case the copyright owners are found. In the opinion of some librarians exceptions for orphaned works introduced by the new law will not overturn the tendency among librarians to refrain from using works of uncertain copyright status (RCL, 2014).

10 The removal of art. 30.1 was criticised by the Society of Documentation and Press Information Centers (Stowarzyszenie Ośrodków Dokumentacji i Informacji Prasowej). 
From the perspective of libraries, the introduction of collective licenses for the use of orphaned works would be a much more practical solution. In my view the administration of collective licenses could be merged with the planned system of compensation fees for borrowing in libraries. The new law however does not mention such a solution.

\section{Libraries Collaborate with Publishers}

Faced with the "drying out of the public domain" i.e. the lack of material for digitization, librarians especially from regional digital libraries try to obtain rights to newer material published in their regions, especially from local newspapers. Many local publishers do not have the means to digitalize their archives. Libraries on the other hand have access to a large number of programs which subsidize digitization. Therefore they offer publishers to scan their archive publications in exchange for permission to make these available in their own digital libraries. In Poland there is a specific situation regarding publishers' production in the period from 1945 to 1989. In the period of the People's Republic of Poland the majority of large-circulation Polish newspapers and journals was published by the large publishing cooperative Robotnicza Spółdzielnia Wydawnicza "Prasa-Książka-Ruch" (RSW "Prasa-Książka-Ruch”). After 1989, some of the titles were privatized while many others simply closed down after the dismantling of the publishing cooperative in 1990. When new owners continue the publication of a title, libraries can enter into a barter treaty on mutual exchange of services and licenses with them. However, in the case of titles which have disappeared from the market after 1990 librarians do not know whom to ask for permission for using them. There has been a number of controversies regarding the principles of the division of assets from RSW "Prasa-Książka-Ruch" as well as decisions made behind closed doors and many cases are still unresolved.

\section{Summary}

The restrictive approach to copyright severely limits the field of activity of digital libraries and makes it impossible for them to meet the expectations of readers who are used to the standards of using commercial search engines and who expect similar ease of use from libraries. Earlier exceptions regarding printed and analogous works have been removed for documents in digital form.

The Polish solutions regarding exceptions from copyright for digital access do not make use of all the possibilities mentioned in international treaties and EU directives on the introduction of permitted public use. Some of the proposed solutions are unpractical and show a lack of understanding regarding the tasks and challenges faced by modern libraries.

Polish libraries interested in digitization will soon also face another problem: the lack of material to digitalize. There are big reserves of printed and audiovisual material published during the Polish People's Republic which have not been digitized yet but much of this material is still subject to litigation concerning ownership while the settling of rights is particularly difficult, especially regarding audiovisual works. 
In this situation, libraries are faced with a problematic dilemma. They risk legal consequences if they want to develop their digital collections and make collections available to users as broadly as possible. The current restrictive development of copyright law risks to leave libraries to the slow death of an outdated institution. If libraries want to protect and strengthen their position they must fight for more favorable legal solutions.

\section{References}

Barański, T. (2010). Typy i formy wydawnicze wyróżnione w polskim prawie autorskim. In: Szczepańska, B., Bednarek-Michalska, B., Stanisławska-Kloc, S. (eds.): Seminarium prawne dla bibliotekarzy cyfrowych, Warszawa, 18 czerwca 2010. Warszawa: Biblioteka Narodowa.

Barta, J.; Markiewicz, R. (2010). Prawo autorskie. Warszawa: Wolters Kluwer Polska.

Directive EC (2001). Directive 2001/29/EC of the European Parliament and of the Council of 22 May 2001 on the Harmonisation of Certain Aspects of Copyright and Related Rights in the Information Society. Official Journal of the European Communities. Legislation, 44, L. 167, 10-19.

Directive EU (2012). Directive 2012/28/EU of the European Parliament and of the Council of 25 October 2012 on certain permitted uses of orphan works. Official Journal of the European Communities. Legislation. 55, L. 299, 5-13.

DMCA (1998). Digital Millennium Copyright Act, Pub. L. No. 105-304, 112 Stat. 2860 (Oct. 28, 1998), codified at 17 U.S.C. 512, 1201-05, 1301-22; 28 U.S.C. 4001.

Halbert, D. J. (2014). The State of Copyright: The Complex Relationships of Cultural Creation in a Globalized World. Abingdon: Routledge.

MBC (nd). Zasady korzystania ze zbiorów [online]. Mazowiecka Biblioteka Cyfrowa [05.11.2015], http://mbc.cyfrowemazowsze.pl/dlibra/text?id=Zasady_korzystania

PwC (2014). Analiza wpływu zjawiska piractwa treści wideo na gospodarkę w Polsce [online]. PwC Polska Sp. z o.o [05.11.2015], http://www.pwc.pl/pl/publikacje/piractwo/analiza_wplywu_zjawiska_piractwa_tresci_wideo_na_gospodarke_w_polsce_raport_pwc.pdf

RCL (2014). Stanowisko organizacji bibliotekarskich [online]. Rządowe Centrum Legislacji [5.11.2015], legislacja.rcl.gov.pl/docs//2/245196/245199/245202/dokument137161.pdf

Sokołowska, D. ed. (2013). Dzieła osierocone: korzystanie z dziet osieroconych w świetle Dyrektywy Parlamentu Europejskiego i Rady 2012/28/UE z dnia 25 października 2012. Poznań: Wyższa Szkoła Umiejętności Społecznych.

Stanisławska-Kloc, S. (2005) Prawo autorskie a biblioteka cyfrowa - opinia prawna sporządzona w ramach projektu KPBC finansowanego z Funduszy Strukturalnych UE [online]. Biuletyn EBIB, 70 [20.03.2015], http://www.ebib.pl/2005/70/stanislawska-kloc.php

Szczepańska, B. ( 2007). Prawo autorskie - ochrona dzieł elektronicznych. In: J. Woźniak-Kasperek \& J. Franke (eds.) Biblioteki Cyfrowe. Projekty, realizacje, technologie. Warszawa: Wydaw. SBP, 51-66.

Szczepańska, B. (2008). Dzieła osierocone Palące problemy, propozycje rozwiązań [online]. Biuletyn $E B I B, 94$ [20.03.2015], http://www.ebib.pl/2008/94/a.php?szczepanska

Szczepańska, B. (2013). Debata o prawie autorskim - w jakim miejscu jesteśmy na początku 2013 roku [online]. Biuletyn EBIB, 138 [05.11.2015], http://open.ebib.pl/ojs/index.php/ebib/article/ view/73/98

Szczepańska, B.; Bednarek-Michalska, B.; Stanisławska-Kloc, S. eds. (2010). Seminarium prawne dla bibliotekarzy cyfrowych, Warszawa, 18 czerwca 2010. Warszawa: Biblioteka Narodowa.

TRIPS (1994). Agreement on Trade-Related Aspects of Intellectual Property Rights, Apr. 15, 1994, Marrakesh Agreement Establishing the World Trade Organization, Annex 1C, The Legal Texts: The Results of The Uruguay Round of Multilateral Trade Negotiations 320 (1999), 1869 U.N.T.S.299, 33 I.L.M. 1197. 
Ustawa (1994). Ustawa z dnia 4 lutego 1994 r. o prawie autorskim i prawach pokrewnych. Dziennik Ustaw, 24, poz. 83.

Ustawa (1994, 2015). Ustawa z dnia 4 lutego 1994 r. o prawie autorskim i prawach pokrewnych. Dziennik Ustaw, 24, poz. 83, consolidated text of September 11, 2015, Dziennik Ustaw, item 1639.

Ustawa (2015). Ustawa z dnia 11 września 2015 r. o zmianie ustawy o prawie autorskim i prawach pokrewnych oraz ustawy o grach hazardowych. Dziennik Ustaw, poz. 1639.

\title{
Biblioteki cyfrowe a prawo autorskie w Polsce
}

\begin{abstract}
Abstrakt
Cel/teza: W artykule przedstawiono wyniki wstępnych badań na temat praw autorskich w polskich bibliotekach cyfrowych. Celem badania było ustalenie najważniejszych kwestii dotyczących praw autorskich oraz problemów, z jakimi borykają się bibliotekarze cyfrowi w Polsce.

Koncepcja/metody badań: Badanie jest oparte o wywiady z polskimi bibliotekarzami cyfrowymi oraz analizę dokumentów dotyczących prawa autorskiego oraz bibliotek cyfrowych w Polsce.

Wyniki i wnioski: Restrykcyjne podejście do praw autorskich ogranicza pole działania bibliotek cyfrowych.

Oryginalność/wartość: Artykuł pokazuje, że bibliotekarze polscy stają przed wyzwaniami wynikającymi z lokalnej specyfiki problemów powodowanych polskim podejściem do wyjątków i ograniczeń prawa autorskiego oraz niejasnych przepisów, szczególnie względem symbolicznej produkcji Polskiej Republiki Ludowej.
\end{abstract}

\section{Słowa kluczowe}

Biblioteki cyfrowe. Prawo autorskie. Dzieła osierocone. Polska.

Dr TERESA SWIECCKOWSKA is an Assistant Professor at the Institute of Information and Book Studies, University of Warsaw. She teaches courses on information ethics, information economy and copyright. Her current research includes the history of copyright, and the historical development of the idea of authorship and intellectual property. She has published articles on copyright issues, open access and and social implications of digital technologies. She is also an author of the book "Public relations and democracy"

Contact to the Author:

t.swieckowska@uw.edu.pl

Institute of Information and Book Studies

University of Warsaw

Nowy Świat 69

00-927 Warsaw, Poland 